Volume 7 Issue 2, June 2020

Nationally Accredited Journal,

Decree No. B/4130/E5/E5.2.1/2019

\title{
Legal Protection of Holders of Land Loss Data In The City Land Office of Kendari
}

\author{
Bahrul Alam ${ }^{1}$ and Akhmad Khisni ${ }^{2}$
}

Abstract. The purpose of this study as follows: 1) To identify and explain the legal protection of land rights holders as a result of the loss of data in the land office Kendari. 2) To identify and explain the impact of the destruction of land records of the rights on public land in Kendari. 3) To identify and explain the legal aspects of the legal protection of land rights data recovery results. The method used by researchers is normative juridical law approach and specification in this study were included descriptive analysis. The source and type of data in this study are primary data obtained from field studies with interview BPN in Kendari.Secondary data were obtained from literature studies. Based on the results of research that legal protection to the right holder on the ground due to the loss of data in the land office are: 1) BPN only provide legal protection to the certificate of land rights have been restored archives; 2) The purpose of data recovery is providing legal protection for the land rights archives destroyed. BPN perform data recovery and ratify certificates and land books and letters Perkaban the measure under Article 18, Act No. 6 of 2010. The destruction of land records can weaken the strength of the evidence as a certificate as evidence of land rights. The impact of the destruction of land records of the rights on public land in Kendari are: 1) the destruction of land records can weaken the strength of the evidence as a certificate as evidence of land rights; 2) the impact of the destruction of land records lead to certificates of land rights before the restored data can not be used as evidence to take legal actions; 3 ) loss or destruction of land records will not necessarily be able to eliminate / abolish the rights to the land concerned. Legal aspects of the legal protection of land rights data recovery results are 1) a substantial aspect, 2) structural aspects, 3) cultural aspects.

Keywords : Legal Protection; Rights to Land; Land.

\section{Introduction}

In its history before the enactment of the BAL are dualism of agrarian law in Indonesia. Dualism in the agrarian law more harm indigenous community groups, because customary laws governing land with indigenous rights is the unwritten law, while on the other on the ground with the right soil west western governed by law is written. Registration for the lands that are subject to western law aimed at ensuring legal certainty, known as Rechts Cadaster or Legal Cadaster.

Article 19 of Act No. 5 of 1960 About the Basic Regulation will be hereinafter referred Agrarian UUPA: Paragraph (1): "In order to ensure legal certainty by the Government held land registration throughout the territory of the Republic of Indonesia in accordance with provisions stipulated by Government Regulation". Paragraph (2): The registration under subsection (1) of this article include: Measurement, mapping, and soil bookkeeping; Registration of rights to land and transfer of such rights; Award letters proof of rights, which apply as evidentiary tool. ${ }^{3}$

Government regulations referred to in Article 19 paragraph (1) BAL is the Government

\footnotetext{
${ }^{1}$ Student Master of Notary Program, Faculty of Law, Sultan Agung Islamic University, Semarang, email: reyhiro77@gmail.com

${ }^{2}$ Lecturer, Faculty of Law, Sultan Agung Islamic University, Semarang

${ }^{3}$ Boedi Harsono, 2008, Hukum Agraria Indonesia: Himpunan Peraturan-peraturan Hukum Tanah, Djambatan, Jakarta, p.11
} 
Regulation No. 10 of 1961 (hereinafter referred to as PP 10 in 1961) of the Land Registry which is then replaced by Government Regulation No. 24 of 1997 on Land Registration will be hereinafter referred to PP 24 of 1997.

As has been described above, that Article $19 \mathrm{BAL}$ regulate the holding of land registration to ensure legal certainty of land rights. Its implementing regulations, set PP 10/1961 mentioned land registration purposes is to guarantee legal certainty, then with PP $24 / 1997$ reaffirmed that the purpose of land registration is not only ensuring legal certainty but more developed towards the legal protection of land rights. ${ }^{4}$

Social reality, is what is felt, what they see, what they hear from others, and what to expect the public about the purpose of obtaining evidence of land rights in the form of a certificate is to want to get legal certainty and legal protection of plots of land owned or under their control. This means that legal protection will be granted after obtaining legal certainty regarding the extent, location, borders, the status of their rights and the documents were used as the base or basic rights can prove that the correct registration certificates were issued legally by BPN.

Certificate of land rights as a result of the end of the process of land registration lists physical data is information about location, boundaries, spacious plot, as well as parts of the building or buildings on top of it when deemed necessary and juridical ie information about the status of land rights and full rights for others who are in it. ${ }^{5}$ Understanding the certificate has been stipulated in Government Regulation No. 24 of 1997 Article 32 paragraph (1) of the Land Registration.

For holders of rights to land, a certificate of land has more value, because compared to other written evidence, the certificate is proof of powerful tools and recognized by law. Moreover, according to Article 31 paragraph (3) of Regulation No 24 of 1997 on land registration has emphatically stated that "certificates should only be submitted to the parties the namely which listed in the land book as the rights holder or any other party in powerfuled by it". So it can be said that the owner of the certificate of land rights is the legal owner of the land objects as mentioned in the above land rights certificates and should be assumed to be true until proven Inversely out of court with the other evidence. in PP

Based on the above problems, the purpose of this study as follows: To identify and explain the legal protection of land rights holders as a result of the loss of data in Kendari city land office; To identify and explain the impact of the destruction of land records of the rights on public land in Kendari; To identify and explain the legal aspects of the legal protection of land rights data recovery results.

\section{Research methods}

In the study the authors using normative juridical approach is used, the research conducted through two stages: the study of literature and field research are merely supporting. Library research is a research conducted to study, examine and analyze secondary data such as primary legal materials, secondary and tertiary. Primary legal materials as legal materials obtained directly from the various legislations ranging from 1945 up to the legal provisions of a technical nature which are closely related to land registration and legal protection. In this study the authors use descriptive research. As for sources and types of data in this study are primary data obtained from field studies with interview BPN in Kendari. And secondary data obtained from the study of literature

\footnotetext{
${ }^{4}$ Muchtar Wahid, 2008, Memaknai Kepastian Hukum Hak Milik Atas Tanah: Suatu Analisis dengan Pendekatan Terpadu Secara Normatif Dan Sosiologis, Republika, Jakarta, p.167

${ }^{5}$ Maria S.W. Sumardjono, 2005, Kebijakan Pertanahan Antara Regulasi Dan Implementasi, Buku Kompas, Jakarta, p.20
} 
Volume 7 Issue 2, June 2020

Nationally Accredited Journal,

Decree No. B/4130/E5/E5.2.1/2019

\section{Results and Discussion}

\subsection{Legal Protection Against Land Rights Holders Due to Loss of Data On City Land Office of Kendari}

Repressive laws related to the protection that the legal protection after disputes, protection of repressive laws aimed at resolving disputes occur. In the case of land disputes, protection of repressive laws that can be given in the form of reversion to the original owners, that is protected by the law is the legal owner of the disputed land. To be able to restore the actual rights to the original owners of course there is a path that must be passed, in case of land disputes, the parties to the dispute will resolve through litigation (court) and non-litigation (out of court). Most cases that can not be resolved by non-litigation will be resolved through litigation path is through the courts. ${ }^{6}$

In the land registration system prevailing in Indonesia, preventive legal protection to rights holders on land that has been registered juridical physical data and the data will be protected from duplication certificate. because of National Land Agency (BPN) will reject the application for registration of other certificates with the same object and this is one form of business of BPN to prevent or minimize the problems of land. Holders of land rights registered land is legally entitled to be protected from duplication of certificates on land. If on top of already existing land rights certificates arise double or if it becomes defective administration of the BPN will cancel certificates issued illegally.Procedures for Granting and Cancellation Rights And the State Land Management Rights, stated: "Cancellation rights to land by the authorized official held if known their disability administrative law in the process of issuing the certificate.

Legal Protection Against Land Rights Holders Due to Loss of Data-Data In Kendari Land Office are: ${ }^{7}$ BPN only provide legal protection to the certificate of land rights have been restored archives; Data recovery purpose is to provide legal protection of land rights archives destroyed. BPN perform data recovery and ratify certificates and land books and letters Perkaban the measure under Article 18, No. 6 of 2010;

\subsection{Impact Against Loss of Land Records Land Rights Society in Kendari}

Described in the discussion above that archives the loss caused no legal certainty, certainty about where it is located, spacious, and boundaries, what their rights and who owns them because the data is stored in the archives. Certainty about the status of their rights, the subject, the rights which encumber the right base as the basis of the registration rights warkah or stored in an archive.

Documents containing administrative data, physical data and juridical data mentioned above are stored at the Land Office in Article 1 paragraph 2 of Regulation of the National Land Agency of the Republic of Indonesia Number: 6 of 2010 Concerning Disaster And Recovery Rights of People Over Assets Land In Disaster region (hereinafter referred to Perkaban 6 of 2010) referred to as the land records: "land records is a recording of activities or events in various forms of media in accordance with the development of information and communication technologies have made and received by the National

\footnotetext{
${ }^{6}$ http://raypratama.blogspot.com/2012/02/hukum-tanah-sebagai-suatu-sistemhukum.html

${ }^{7}$ Results of interviews with $\mathrm{Hj}$. Rahmatia.S, sit. Head of the Tata business Kendari Land Office, on January 7,2020 at 10:45 pm
} 
land Agency of the Republic of Indonesia. ${ }^{8}$

The discussion back to the Preamble Perkaban 6 of 2010 b stated that the damage or destruction of land records because a disaster can result in loss of community rights over land assets in the disaster area. Meaning of words missing verbs according to the Dictionary of Indonesian Language, interpreted no longer missing, disappeared, or delete9.

Completeness of supporting data can be used to avoid their dual ownership on the field / area of land. However, Maria. SW added that until there are two or more people vying for the same land area, it can be reached through mediation. The loss of legally formal land records will weaken the strength of the entry into force when there is a dispute because of the strength of proof depends on warkah or files stored in the Land Office or Regional Office or BPN RI or elsewhere that stores the file. In the event of administrative disputes in the Administrative Court or the dispute in general court, the Land Office (BPN) can not prove that the certificate quo is a product, therefore the certificate can be canceled, as in the case Jurisprudence No. 24 / Pdt.G / 2010 / PN. Cj in which the verdict canceling the execution of the auction. The judge stated in its legal considerations Certificate of 106 product Sukasari Village Cilaku District of Cianjur is not clear, because the archives destroyed by fire BPN Cianjur can not prove that the Certificate of Property Rights Sukasari Village 106 is a product. ${ }^{10}$

Certificate of land rights has two (2) different sides, namely on the one hand as a civil certificate is a proof of ownership, on the other hand the certificate is a form of decision that determination (beschiking) ${ }^{11}$ and a recognition of the country. Therefore, the cancellation of the certificate does not necessarily cancel rights court of justice, meaning that land rights can be filed again by the holders of land rights to the Land Office.

Impact Against Loss of Land Records Land Rights Society in Kendari : Impact Loss / Loss records at the land office can weaken the strength of evidence a certificate as evidence of land rights; Impact Missing / destruction of records at the land office resulted certificate of land rights before the restored data can not be used as evidence to take legal actions;

\subsection{Legal Aspects of Legal Protection Against Land Rights Data Recovery Results}

The solution to the problems that made the BPN is pulling all the certificates on land rights that exist in the community or elsewhere for the restored data. As we know that in a negative system of land registration is not accompanied by a legal instrument amplifier, still contains weaknesses, to ensure that legal protection obtained is still relative. This situation shows that the system of land registration is currently not provide legal protection of land rights effectively, this condition weakened again by missing or destruction of records. Where the system is negatively land registry file in which there are authentic or legitimate documents (the right base, evidence of acquisition, evidence of physical mastery, the deed of sale, notarization, etc.) is required when there is a

\footnotetext{
${ }^{8}$ Results of interviews with Hairuddin, SH Kasubsi BPN Land Registry of Kendari, on January 7, 2020, 13:15 pm

${ }^{9}$ Ministry of Education and Culture, 1990, Kamus Besar Bahasa Indonesia, Balai Pustaka, Jakarta, p.306

${ }^{10}$ Results of interviews with $\mathrm{Hj}$. Rahmatia.S, sit. Head of the Tata business Kendari Land Office, on January 7, 2020 at 10:45 pm

${ }^{11}$ Marbun, SF 2003, Peradilan Administrasi dan Upaya Administrasi Indonesia, Cetakan Kedua, UII Press, Yogyakarta
} 
Volume 7 Issue 2, June 2020

Nationally Accredited Journal,

Decree No. B/4130/E5/E5.2.1/2019

dispute/conflict.

Efforts to achieve legal certainty and the protection of land rights that have been registered face many obstacles, both substantial, structural, and culture. To analyze the authors use Legal System Theory Friedman, Lawrence M. Friedman mention the success or failure of the operation of the law, depends on three elements: structure, substance and legal culture, wherein one another have a relationship in relation to the law. The substance of the Law is the norm (rules / decisions), which is the result of a legal product. Legal structure that is created by the legal system may be to provide services and law enforcement. Legal culture is an idea, behavior, desires, opinions, and values associated with the law (positive / negative). ${ }^{12}$

Legal Aspects of Legal Protection Against Land Rights Data Recovery results are: ${ }^{13}$

- Substantial aspects, Article 18 Perkaban No. 6 of 2010 there are still many weaknesses: 1). there is a shortage of the rule of law, where Perkaban No. 6 of 2010 is incomplete, Article 18 Perkaban No. 6 of 2010, which was restored only juridical and administrative data, and does not regulate the physical data recovery; 2 ). there are inconsistencies with the Law and Regulation 24 of 1997 on Land Registration; 3). data recovery activities (routine) is not regulated in non-tax revenues (Non Tax Revenue) either PP 13 in 2010 which was later replaced by Regulation 128 in 2015 concerning the applicable non-tax revenues in the National Land Agency. Data recovery costs are determined based on the policy Head of the Land Office, this can pose a potential loss to the state and provide a loophole for unscrupulous officials BPN to charge fees beyond the requirements; 4). no SOP (standard operating procedures), regarding the procedures, timing of completion and the cost; 5). Certificate data recovery results, the manufacturing procedure does not qualify the formal and material an authentic act;

- Structural aspects that hinder the implementation of data recovery, among others: 1 ). The existence of a different understanding between BPN officials and the public in understanding the terms and conditions and time in data recovery on the ground, and less response from Person BPN and parties / other relevant agencies (village or village chief, sub-district, PPAT / Notary); 2). Not orderly protocol management or administration of land or all PPAT's, village, village chief, sub-district or Notary, cause data retrieval less land to recover data up to do, because these data are missing or are in an unknown place. 3). and poor land administration in the past both in the BPN or in the village, Head, Sub, or PPAT / Notary, the data resulting data taken from them for data recovery, become less valid;

- Cultural aspects: 1). Lack of public awareness of the importance of data recovery and some people are reluctant to provide the original certificate for the restored data; 2). Apparatus BPN who are not professional in providing services result in service becomes long, and in carrying out its duties and responsibilities, sometimes the elements can not be separated from the influence of negative influences (bribery, extortion) and take advantage of the absence of archives for instance apply for the land rights of others, or apply for a certificate whose status has changed or is no longer valid, and others.

12 Nihayatul Ifadhloh, http://nihayatulifadhloh.blogspot.co.id/2015/06/analisis-kasusmenggunakan-teori-sistem.html, Downloaded on 24 September 2016 pukul.1300 pm.

${ }_{13}$ Results of interviews with Hairuddin, SH Kasubsi BPN Land Registry Kendari, on January 7, 2020, 13:15 pm 


\section{Closing}

\subsection{Conclusion}

Based on the results of research and discussion in the previous chapter, it can be concluded:

- Legal Protection Against Land Rights Holders Due to Loss of Data On State Land Office of Kendari : BPN only provide legal protection to the certificate of land rights have been restored archives; Data recovery purpose is to provide legal protection of land rights archives lost / destroyed. And BPN perform data recovery and ratify certificates and land books and letters Perkaban the measure under Article 18, No. 6 of 2010;

- The impact of the loss / Loss of Land Records, Against Land Rights Society in Kendari: Impact of loss / destruction of land records, can weaken the strength of evidence certificate, as evidence of land rights; The impact of the loss / destruction of land records, resulting in land rights certificate before the restored data can not be used as evidence to take legal actions; loss or destruction of land records, not necessarily to eliminate / abolish the rights to the land concerned

- Legal Aspects of Legal Protection Against Land Rights Data Recovery Results: Substantial aspects of Article 18 Perkaban No. 6 of 2010; structural aspects; Cultural aspects:

\subsection{Suggestion}

- Legal protection of the holders land rights in this community first of all require the availability of devices written law fully and clearly implemented in a manner consistent with the spirit and content of its provisions, therefore, expected to legislation in Indonesia mainly deals in the land sector needs to be revised in accordance the circumstances and conditions present.

- The government needs to arrange the socialization of legislation in land, so that people understand and know the importance of proof of ownership rights over land they have.

\section{References}

[1] Boedi Harsono, 2008, Hukum Agraria Indonesia: Himpunan Peraturan-peraturan Hukum Tanah, Djambatan, Jakarta

[2] Ministry of Education and Culture, 1990, Kamus Besar Bahasa Indonesia, Balai Pustaka, Jakarta

[3] http://raypratama.blogspot.com/2012/02/hukum-tanah-sebagai-suatusistemhukum.html,

[4] Marbun, SF 2003, Peradilan Administrasi dan Upaya Administrasi Indonesia, Cetakan Kedua, UII Press, Yogyakarta

[5] Maria SW Sumardjono 2005, Kebijakan Pertanahan Antara Regulasi Dan Implementasi, Buku Kompas, Jakarta

[6] Muchtar Wahid, 2008, Memaknai Kepastian Hukum Hak Milik Atas Tanah: Suatu Analisis dengan Pendekatan Terpadu Secara Normatif Dan Sosiologis, Republika,Jakarta.

[7] NihayatulIfadhloh,http://nihayatulifadhloh.blogspot.co.id/2015/06/analisis-kasusmenggunakan-teori-sistem.html, Downloaded on 24 September 2016 pukul.1300 pm. 